\title{
EFFECT OF MANGOSTEEN PEEL EXTRACT ON BONE FRACTURE HEALING
}

\author{
BRENT R. IOYAH, WIDURINI DJOHAN, ERIK IDRUS*
}

Department of Oral Biology, Faculty of Dentistry, Universitas Indonesia, Jakarta, 10430, Indonesia. Email: erik.idrus@gmail.com Received: 17 November 2018, Revised and Accepted: 07 February 2019

\section{ABSTRACT}

Objective: Healing of bone fractures is mediated through antioxidants; however, increased free radical levels at the site of fracture inhibit bone healing. Mangosteen peel has antioxidant, anti-inflammatory, antitumor, antiviral, antibacterial, antifungal, antihistaminic, antimalarial, and other beneficial properties as it contains many active substances such as xanthones, anthocyanins, phenols, and tannins. In this study, we aimed to determine the effects of mangosteen peel extract on bone fracture healing.

Methods: We used six mice with left and right femoral fractures (12 femurs). Mangosteen peel extract was applied to the left femurs of the six mice at two dosages (20 and $40 \mathrm{mg} / \mathrm{kg}$; three femurs each) on days 2, 4, and 6 after fracture; saline was injected into the right femurs of all six mice. On day 7 , all the animals were sacrificed, and femur defect diameter was evaluated using dental digital radiography.

Results: The femoral defect diameter in mice treated with $40 \mathrm{mg} / \mathrm{kg}$ dose of mangosteen peel extract was less than that in mice treated with saline, although the difference was not significant.

Conclusion: Application of a $40 \mathrm{mg} / \mathrm{kg}$ dose of mangosteen peel extract promotes bone fracture healing.

Keywords: Bone fracture healing, Dental digital radiography, Mangosteen peel extract.

(c) 2019 The Authors. Published by Innovare Academic Sciences Pvt Ltd. This is an open access article under the CC BY license (http://creativecommons. org/licenses/by/4. 0/) DOI: http://dx.doi.org/10.22159/ijap.2019.v11s1.202

\section{INTRODUCTION}

Mangosteen fruit (Garcinia mangostana Linn.) comes from tropical forest areas in Southeast Asia and can be easily found in Indonesia. The mangosteen pericarp has long been used in Southeast Asia as a traditional medicine for treating stomatitis, dysentery, cystitis, diarrhea, gonorrhea, and exim. Current research on mangosteen peels has shown that they contain bioactive substances such as xanthones, anthocyanins, phenols, tannins, and other derivatives. Several of these bioactive compounds and their derivatives reportedly have a significant pharmacological activity such as antioxidant, antihistaminic, anti-inflammatory, antibacterial [1], and anticancer [1,2] properties.

Fracture is the discontinuity of bone due to trauma or a continuous and pathologic force. Bone fracture cases are considered a serious problem in Indonesia. Reportedly, the total number of bone fracture cases in Indonesia is more or less 1.3 million cases every year, which is highest among the Southeast Asian countries. A survey showed that the prevalence of lower extremity fractures caused by accidents was around $46.2 \%$; these fractures reportedly led to mortality (25\%), physical disability (45\%), and depression and psychological distress (15\%), and only $10 \%$ cases were able to heal [3].

A fractured bone normally has the ability to heal itself. According to Altizer (2002) and Robert (2009), bone healing comprises five phases. (1) Hematoma phase (1-3 d after fracture); during this phase, blood coagulation, vessel dilation, debris formation, and exudation of fibrincontained plasma occurs. (2) Cartilage formation phase (3 d-2 w): During this phase, acute inflammation, formation of fibrocartilage, and periosteum elevation occur. (3) Callus formation phase (2-6 w): During this phase, medulla callus, bone continuity until the formation of trabecular or cancellous bone that replaces the callus. (5) Consolidationremodeling phase $(6 \mathrm{w}-1 \mathrm{y})$ : During this phase, the bone shape or function alters so as to enable the bone to function best [4].
In the hematoma phase, the immune system invades the fracture area, causing inflammation that initiates healing and formation of granulation tissue [5]. However, neutrophil activity within the fracture area produces high levels of free radicals, which have been shown to inhibit bone healing by damaging cell membranes and triggering cell lysis. Antioxidants are needed to inhibit such free radical activity [6-8]. In the present study, we investigated the antioxidant effects of mangosteen peel extracts on bone fracture healing in mice.

\section{METHODS}

\section{Animals and bone defect generation}

Dissection instruments were sterilized using betadine solution or $70 \%$ alcohol. Mice $(\mathrm{n}=7)$ were anesthetized using an intraperitoneal injection containing $80 \mathrm{mg} / \mathrm{kg}$ ketamine and $10 \mathrm{mg} / \mathrm{kg}$ xylazine. The mice thighs were shaved to ease the dissection procedure.

The mice thigh skin was smeared with betadine or $70 \%$ alcohol. The femur was then exposed using a scalpel and no. 12 surgical blades. Defects were made in each femur with a diamond round bur using a low-speed micromotor until reaching the depth of the bur head. Defects were made in both the left and right femurs of all the animals using the same technique. One mouse was sacrificed by directly placing it inside an ether-filled container, and the femurs from both the legs were used as the defect standard measurement (control). One ear of each of the other six mice was marked by cutting a small notch out of it using surgical scissors. Simple interrupted suturing was performed using nonresorbable silk sutures to facilitate the easy reopening of the incision if a femur sample was needed for further testing. The suturing was performed on muscle and skin tissues using the same suture pattern on each leg. During suturing, the needle can be held only using a needle holder in the dominant hand to prevent a possible needle punctured wound to the operator's hand. The muscle and skin tissues could be held using tissue forceps in the non-dominant hand. After suturing, the area was again cleaned using betadine or $70 \%$ alcohol. Mice were returned to their cages and monitored before mangosteen peel extract application. 


\section{Drug treatments}

Mangosteen peel extract was applied, and saline solution was administered to the mice through an intraperitoneal injection $(0.2 \mathrm{~mL}$ saline/injection) in a localized position on days 2, 4, and 6 after making the defects. Three mice received $20 \mathrm{mg} / \mathrm{kg}$ mangosteen peel extract, and three received $40 \mathrm{mg} / \mathrm{kg}$ extract in the left leg, and all six mice received a saline solution in the right leg. Mice were anesthetized using a centrifuge tube filled with cotton and ether before each injection. On day 7 after fracture, mice were euthanized by directly placing them inside an ether-filled container, and femur samples were collected. The samples were stored in centrifuge tubes filled with $70 \%$ alcohol until radiographic image processing.

\section{Radiography}

Stored femur samples were secured using sellotape and then glued before being exposed to X-ray using dental digital radiography. Each radiograph contained a pair of femur samples from the same mouse. After images were digitized, the measurement scale was calibrated, and defect diameters were measured.

\section{Statistical analysis}

Data were analyzed using one-way analysis of variance (ANOVA) and a post hoc test. Defect diameters were measured using Digora for Windows at the end of the treatment period and mean defect diameters after extract application and saline administration were evaluated using SPSS.

\section{RESULTS}

Fig. 1 shows representative radiographic images of control and salinetreated mouse fracture defects.
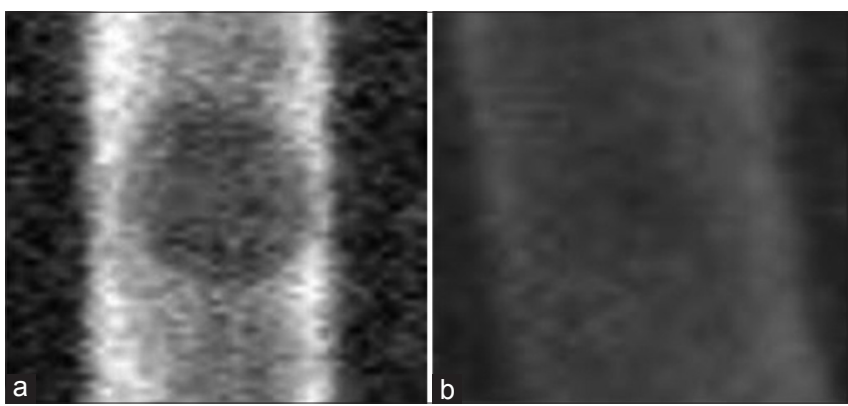

Fig. 1: Radiographic images of mouse femurs (a) control femur (untreated) (b) saline-treated mouse femur after $7 \mathrm{~d}$
The mean defect diameter in the mice 7 days after fracture was $1.17 \mathrm{~mm}$ for the femurs with $20 \mathrm{mg} / \mathrm{kg}$ dosage of extract, $1.20 \mathrm{~mm}$ for the femurs with the $40 \mathrm{mg} / \mathrm{kg}$ dosage, and $1.0678 \mathrm{~mm}$ for the saline-treated femurs, indicating greater healing with saline. However, both ANOVA and post hoc test results showed that there was no significant difference in the defect diameter among the three treatment groups ( $p>0.05)$

\section{DISCUSSION}

After fracture, the bone heals itself in five main phases. During the hematoma phase, phagocytic cells, such as neutrophils, enter the fracture area, and generate free radicals like nitric oxide, which modulate fracture healing $[4,7]$. However, these free radicals have also been shown to inhibit or even damage the bone healing process [7]. A previous study showed that xanthone derivatives in mangosteen peel extract could prevent free radical damage, which is similar to the role played by Vitamin C [9]. Therefore, the present study investigated the antioxidant effects of mangosteen peel extract on bone fracture defects in the femur of mice.

Our study results demonstrated that administration of mangosteen peel extract in dosages of $20 \mathrm{mg} / \mathrm{kg}$ and $40 \mathrm{mg} / \mathrm{kg}$ inhibited bone healing, though not significantly, as defect diameters in femurs treated with both the dosages were higher than that in saline-treated femurs (Fig. 2). This result is in line with a study by Diwan et al., who showed that free radicals, such as nitric oxide, are actually necessary in the bone healing process [10]. Thus, local treatment with antioxidants present was detrimental to bone repair.

The $20 \mathrm{mg} / \mathrm{kg}$ dosage of mangosteen extract was set as baseline based on the research by Shibata et al. who stated that this dosage is pharmacologically effective against cancer yet nontoxic [2]. In another research on anticancer agents, it was reported that mangosteen peel extract dosage of not only $20 \mathrm{mg} / \mathrm{kg}$ but also $40 \mathrm{mg} / \mathrm{kg}$ showed a significant effect [11]. Furthermore, Kosem et al. showed a mangosteen peel extract dosage of $\leq 50 \mathrm{mg} / \mathrm{kg}$ to be nontoxic [12]. Thus, the above dosages were chosen in the present study.

The mangosteen pericarp is known to have strong antioxidant properties and has been predicted to accelerate the healing process $[13,14]$. Previously, Gokturk et al. showed that defects created in mouse femurs treated only with saline healed within 22 days, as observed radiographically [7]. We did not wait for 22 days based on the assumption that it would not be easy to radiographically evaluate the healed defect (especially if it gets closed). Thus, the mice were kept alive only for 7 days so that the mice femur bone with the defect could be clearly evaluated radiographically.

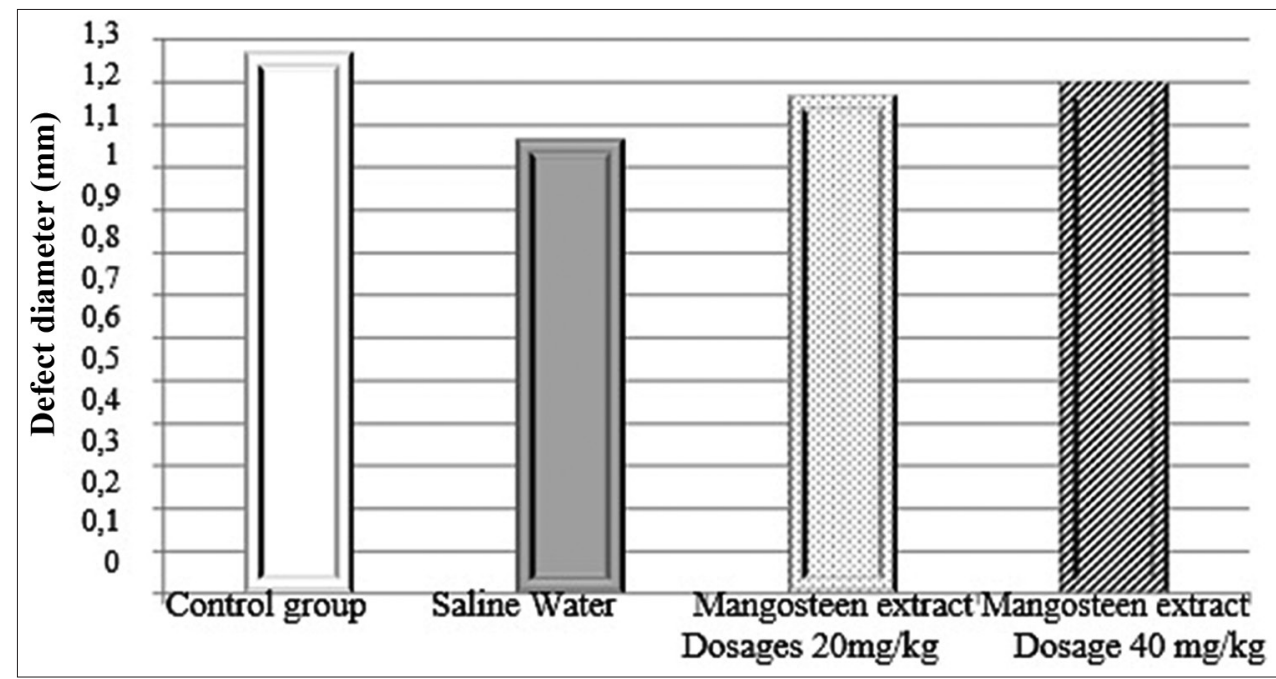

Fig. 2: Defect diameter of Femur after treatment 
The radiographic evaluation performed in this study was similar to that performed by Gokturk et al. who used dental digital radiography [7] was able to show that administration of mangosteen peel extract actually slowed the healing process. It is possible that extended treatment may show more significant results. This tool offers the advantage of enabling radiographic image manipulation, such as setting the contrast and magnification. Furthermore, the required measurements can be appropriately taken and image acquisition time is short. However, this tool also has certain disadvantages. As the acquired image is twodimensional, the defect diameter cannot be determined; furthermore, the subjectivity from the border of radiopaque-radiolucent became the limitation of this research.

\section{CONCLUSION}

Our results showed that the defect diameter size in femurs treated with mangosteen peel extract at a dosage of $40 \mathrm{mg} / \mathrm{kg}$ was decreasing. This showed the healing process of fractures.

\section{CONFLICTS OF INTEREST}

The author reports no conflicts of interest.

\section{REFERENCES}

1. Nugroho AE. Garcinia mangostana L.: From wasted fruit skin to become a candidate for a drug. Majalah Obat Tradisional 2011;16:64-9.

2. Shibata MA, Linuma M, Morimoto J, Kurose H, Akamatsu K, Okuno Y, et al. $\alpha$-Mangostin extracted from the pericarp of the mangosteen (Garcinia mangostana Linn) reduces tumor growth and lymph node metastasis in an immunocompetent xenograft model of metastatic mammary cancer carrying a p53 mutation. BMC Med
2011;9:69.

3. Ropyanto CB. Analysis of Factors Related to Patient Functional Status After Open Reduction Internal Fixation (ORIF) Fracture of Lower Extremities in the Hospital Orthopedics Prof Soeharso Surakarta. Depok: Universitas Indonesia; 2011.

4. Aryani R. Phenomenology Study: Experience of Patients Who has a Fracture of the Lower Limb with the Installation of an External Fixator at Fatmawati General Hospital. Depok: Universitas Indonesia; 2011.

5. Geneser F. Histology Textbook. $1^{\text {st }}$ ed. Jakarta: Bina Rupa Aksara; 1994. p. 228-9.

6. Borhanuddin B, Fozi NF, Mohamed IN. Vitamin E and the healing of bone fracture: The current state of evidence. Evid Based Complement Altern Med 2012;2012:684510.

7. Gokturk E, Turgut A, Baycu C, Gunal I, Seber S, Gulbas Z. Oxygenfree radicals impair fracture healing in rats. Acta Orthop Scand 1995;66:473-5.

8. Sheweita SA, Khoshhal KI. Calcium metabolism and oxidative stress in bone fractures: Role of antioxidants. Curr Drug Metab 2007;8:519-25.

9. Kondo M, Zhang L, Ji H, Kou Y, Ou B. Bioavalability and antioxidant effects of a xanthone rich mangosteen (Garcinia mangostana) product in humans. J Agric Food Chem 2009;57:8788-92.

10. Diwan AD, Wang MX, Jang D, Zhu W, Murrel GA. Nitric oxide modulates fracture healing. J Bone Miner Res 2000;15:342-51.

11. Akao Y, Nakagawa Y, Iinuma M, Nozawa Y. Anti cancer effect of xanthones from pericarps of mangosteen. Int J Mol Sci 2008;9:355-70.

12. Kosem N, Ichikawa K, Utsumi H, Moongkarndi P. In vivo toxicity and antitumor activity of mangosteen extract. J Nat Med 2013;67:255-63.

13. Muchtaridi M, Wijaya CA. Anticancer potential of -mangostin. Asian Journal of Pharmaceutical and Clinical Research 2017;10:440-5.

14. Abuzaid AS, Sukandar EY, Kurniati NF, Adnyana IK. Preventive effect on obesity of mangosteen (garcinia mangostana 1.) Pericarp ethanolic extract by reduction of fatty acid synthase level in monosodium glutamate and high-calorie diet-induced male Wistar rats. Asian Journal of Pharmaceutical and Clinical Research 2016;9:257-60. 